\title{
CORRESPONDENCE
}

\section{CORNEO-SCLERAL SUTURE IN CATARACT EXTRACTION}

To the Editors of THE BRITISH JOURNAL OF OPHTHALMOLOGY.

SIRS,-I have read with interest Mr. Affleck Greeves' letter in the correspondence section of the July number criticising the corneoscleral suture in cataract extraction. (See Brit. Jl. of Ophthal., May, 1938.)

I agree with his preference for a conjunctival stitch on the grounds that a more liberal conjunctival flap is obtainable by this method of suturing than with the corneo-scleral stitch. The tensile quality of the conjunctiva and its friability is so variable in elderly persons that the effect of a purely conjunctival suture in controlling the cataract section wound in the manner desired is, I believe, considerably less constant than in the case of a suture traversing such tissues as the cornea and sclera, the tensibility of which is relatively very small compared with the conjunctiva.

$I$ intend to try a series of cases using a slight modification of Mr. A. Greeves' stitch by passing the upper traverse of the stitch not only through conjunctival and subconjunctival tissue, as he recommends, but also through the superficial layers of the sclera.

I feel that by this means the suture would be less likely to be affected by stretching or sliding of the bulbar conjunctiva above the section wound.

I am interested to read Mr. A. Greeves' statement that hyphaema " is a complication with which I have fortunately not been troubled."

I am, yours truly,

H. B. Stallard.

35, Harley Street, W.1 July 14, 1938 .

\section{NOTES}

Royal Society of Medicine: Section of Ophthalmology
THE following officers have been nominated for the session 1938-39:-President, Malcolm Hepburn; Immediate Past President, W. H. McMullen; Vice-Presidents, A. D. Griffith, M. L. Hine, D. LeightonDavies, P. G. Doyne, Percival Hay, T. Snowball; Hon. Secs., E. F. King, C. D. Shapland. Members of Council: Physicians, E. A. Blake Pritchard, S. H. Browning, R. A. Hickling. Metropolitan members: A. C. Hudson, A. Rugg-Gunn, B. W. Rycroft, WingCommander Livingston, T. K. S. Lyle, A. F. MacCallan, Hon. G. J. O. Bridgeman, J. H. Doggart, Jean Dollar. Provincial 